\title{
Combined Resonant Column and Cyclic Triaxial Tests for Measuring Undrained Shear Modulus Reduction of Sand With Plastic Fines
}

REFERENCE: El Mohtar, Chadi S., Drnevich, Vincent P., Santagata, Marika, and Bobet, Antonio, "Combined Resonant Column and Cyclic Triaxial Tests for Measuring Undrained Shear Modulus Reduction of Sand With Plastic Fines," Geotechnical Testing Journal, Vol. 36, No. 4, 2013, pp. 1-9, doi:10.1520/GTJ20120129. ISSN 0149-6115.

\begin{abstract}
This paper investigates the undrained shear stiffness of sand-bentonite specimens (with $0 \%, 3 \%$, and $5 \%$ bentonite by dry mass of the sand) prepared at the same skeleton void ratio $\left(D_{\text {rsk }}=35 \%\right.$ to $\left.40 \%\right)$ using a dry pluviation technique. The experimental program consisted of (1) small strain tests using a resonant column apparatus and (2) large strain tests using a cyclic triaxial apparatus. The resonant column tests were performed at three confining stress levels $(50,100$, and $193 \mathrm{kPa})$ under drained and undrained conditions. A comparison of the shear modulus reduction with shear strains for both drained and undrained conditions is presented; the effects of changes in effective stresses and the rate of modulus reduction as a function of the effective stress are discussed to describe the discrepancy between the two sets of data. The results show a marginal decrease in $G_{\max }$ for specimens with bentonite, which is attributed to the presence of bentonite at the sand grain contacts. However, the presence of bentonite increases the linear elastic threshold, particularly in the case of undrained tests, in which a noticeable delay in excess pore pressure generation was measured. The strain level required in order to initiate excess pore pressure generation increased with increasing bentonite content. A similar trend was noted in cyclic triaxial tests, in which, for a given strain, specimens with bentonite generated lower excess pressure than sand specimens tested under similar conditions. Finally, a combined normalized $G / G_{\max }$ curve from both tests is presented for specimens with $0 \%, 3 \%$, and $5 \%$ bentonite at $100 \mathrm{kPa}$.
\end{abstract}

\section{Nomenclature}

$A_{\mathrm{s}}=$ area of the specimen after consolidation

$a$ and $b=$ fitting parameters determined using the root mean square error method

$C_{\mathrm{u}}=$ coefficient of uniformity

$D_{\text {rsk }}=$ skeleton relative density

$D_{50}=$ average particle size

$E=$ Young's modulus

$e_{\max }=$ maximum void ratio

$e_{\min }=$ minimum void ratio

$e_{\mathrm{sk}}=$ skeleton void ratio

$G=$ shear modulus

$G_{\max }=$ maximum shear modulus

$G_{\mathrm{s}}=$ specific gravity

$G_{\mathrm{U}}=$ measured undrained shear modulus

$G_{\text {U-Corrected }}=$ undrained shear modulus at a given shear strain amplitude corrected for loss of effective stresses

$L_{\mathrm{DA}}=$ double amplitude load (twice the deviatoric vertical stress $d \sigma_{\mathrm{v}}$ )

Manuscript received June 27, 2012; accepted for publication April 5, 2013; published online May 14, 2013.

${ }^{1}$ Dept. of Civil, Architecture, and Environmental Engineering, The Univ. of Texas at Austin, Austin, TX 78712, United States of America.

${ }^{2}$ School of Civil Engineering, Purdue Univ., W. Lafayette, IN 47907, United States of America.

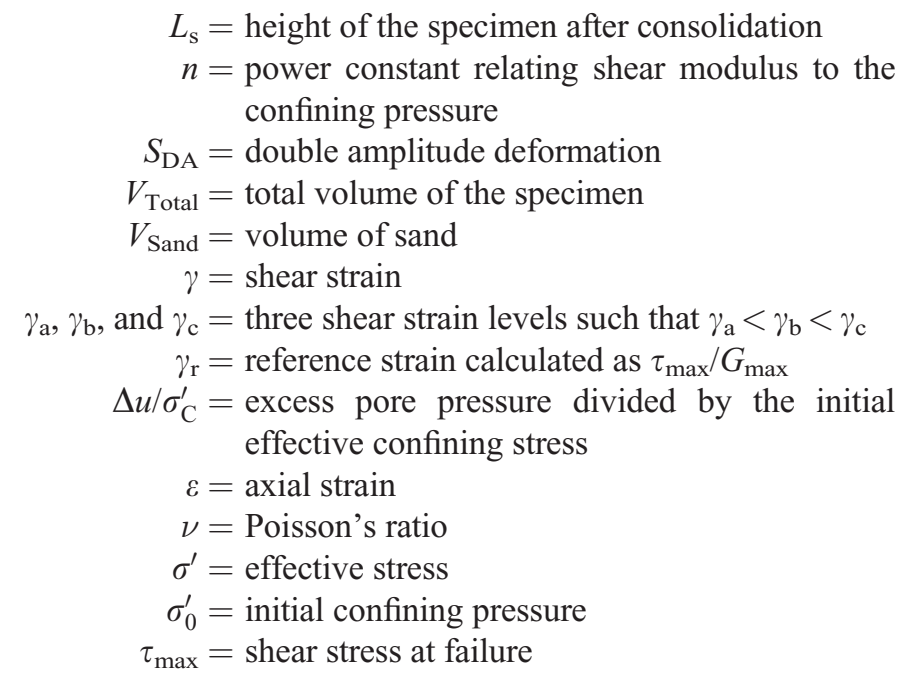

\section{Introduction}

During earthquakes, shear stress-wave propagation subjects soils to cyclic shear strains that, if high enough, can lead to the rearrangement of particles. For saturated soils, under undrained loading, this rearrangement of particles leads to the generation of excess pore pressure, which causes the effective confining stresses to decrease. For a given applied cyclic shear stress, the magnitude of the shear strains depends on the soil stiffness, which in turn 
depends on the level of shear strain and excess pore pressure (to determine the change in effective confining stresses). Liquefaction can be induced if the cyclic strains are high enough to generate excessive pore pressure leading to a complete loss of the effective stresses. Understanding shear modulus reduction under undrained conditions with increasing shear strains and excess pore pressures is critical to the prediction of ground movements. However, the traditional $G / G_{\max }$ curve is defined at a constant effective stress, rather than under undrained conditions in which the excess pore pressure will reduce the effective stresses as the shear strain increases.

Observations in the field after earthquakes indicate that the presence of fines might increase the liquefaction resistance of cohesionless soils, and much work has been done in the past years in the laboratory to explore this effect further. Particularly, there is general agreement that the liquefaction resistance of a soil increases with the plasticity index of the fines. This has been confirmed by laboratory results (Ishihara and Koseki 1989; Yasuda et al. 1994) and by field observations (Wang 1979; Seed et al. 1983; Tokimatsu and Yoshimi 1983; Ishihara 1993, 1996), and it is reflected in recommendations for designs such as those contained in the Chinese Criterion (Wang 1979) and those provided by Ishihara and Koseki (1989) and Ishihara (1993), who propose increasing the cyclic resistance ratio factor based on the plasticity index (PI) for soils with PI $>10$. Recently, the possible application of bentonite grout has been studied for improving soil performance under static and seismic loading conditions (Haldavnekar et al. 2003; El Mohtar et al. 2008b; Rugg et al. 2011). This study investigates whether undrained modulus reduction curves can be obtained in the lab for sand with $0 \%, 3 \%$, and $5 \%$ bentonite (by dry mass of sand) and compares the drained and undrained curves in order to understand the modulus reduction under undrained conditions. The percentage of bentonite was limited to $5 \%$ to allow the bentonite to freely swell within the void space. At the skeleton relative density used and the free swell potential of the bentonite, using higher percentages of bentonite would have interfered with the free swelling of bentonite because of limited pore space.

The shear modulus of a soil is affected by the cyclic strain amplitude, mean principal effective stress, void ratio, overconsolidation ratio, PI, and number of loading cycles. The back bone curve or modulus reduction curve is usually used to determine the change in shear stress or shear modulus with shear strain, respectively. Seed and Idriss (1970), Zen et al. (1978), Dobry and Vucetic (1987), Vucetic and Dobry (1991), and Ishibashi and Zhang (1993) all studied the change in $G / G_{\max }$ with strain as a function of PI, effective confining stress, and number of loading cycles.

Several stress-strain models have been proposed to model the non-linear behavior of soil (Duncan and Chang 1970; Hardin and Drnevich 1972; Fahey and Carter 1993). A similar hyperbolic model was used in this study to determine the shear modulus reduction, with both drained and undrained conditions, using resonant column tests. The results are combined with the cyclic triaxial test results in an attempt to generate an undrained $G / G_{\max }$ reduction curve over a wide range of strains.

\section{Experimental Program}

\section{Materials}

The experimental work focused on the investigation of the mechanical behavior of clean sand and sand with $3 \%$ and $5 \%$ bentonite (by dry mass of the sand) through resonant column and cyclic triaxial tests. Graded Ottawa sand C 778 was used for the tests in this study. C 778 is a uniform $\left(C_{\mathrm{u}}=1.7\right)$, clean, fine to medium sand $\left(\mathrm{D}_{50}=0.4 \mathrm{~mm}\right)$ with $2 \%$ to $5 \%$ of the sand finer than $0.075 \mathrm{~mm}$. It has a specific gravity $G_{\mathrm{s}}=2.65$ and maximum and minimum void ratios $e_{\max }=0.78$ and $e_{\min }=0.48$, respectively. Wyoming bentonite (CP-200), commercially available from VOLCLAY, with at least $70 \%$ of the sand finer than $0.075 \mathrm{~mm}$ and a minimum free swell of $8 \mathrm{ml} / \mathrm{g}$, was used as the plastic fines. Deionized, de-aired water was used to flush and saturate the cyclic triaxial and resonant column specimens.

\section{Specimen Preparation}

The specimen preparation method was modified from standard procedures ASTM D4015 and ASTM D5311 to accommodate the specific nature of the tested materials. Both resonant column and cyclic triaxial specimens were prepared using the same procedure. The sand and the desired percentage of bentonite were placed in a closed plastic container (a modified $75 \mathrm{~mm} \times 150 \mathrm{~mm}$ cylinder used for testing concrete) fitted with a valve to allow sand pluviation. The container, with its long axis in the horizontal direction, was shaken by hand for 15 minutes. This was done so that the sand and bentonite were spread over a larger area to minimize the height of the material in the container and therefore reduce the chances of segregation during mixing. After the mixing was complete, the mixture was air-pluviated (using a tube connected to the valve at the base of the mixing container) into a triaxial split mold $(D=70 \mathrm{~mm}, H=200 \mathrm{~mm})$ to prepare specimens $160 \mathrm{~mm}$ tall. For clean sand specimens, the sand was air pluviated using a funnel directly into the split mold that was lined with a latex membrane held in place by applying vacuum between the mold and membrane. If needed, the mold was then tapped on the sides to achieve the desired skeleton void ratio $e_{\mathrm{sk}}$. For all the tests presented in this paper, the target value for the skeleton relative density $D_{\text {rsk }}$ was $35 \% \pm 5 \%$. The skeleton void ratio and skeleton density can be calculated using Eqs 1 and 2 .

$$
\begin{gathered}
e_{\mathrm{sk}}=\frac{V_{\text {Total }}-V_{\text {Sand }}}{V_{\text {Sand }}} \\
D_{\text {rsk }}=\frac{e_{\max }-e_{\mathrm{sk}}}{e_{\max }-e_{\min }}
\end{gathered}
$$

where:

$V_{\text {Total }}=$ total volume of the specimen,

$V_{\text {Sand }}=$ volume of sand in the specimen (calculated from the dry mass and specific gravity of the sand), and

$e_{\max }$ and $e_{\min }=$ maximum and minimum void ratio of the clean sand, respectively.

The sand-bentonite mixtures were air-pluviated into the mold with all drainage lines, porous stone, and filter papers dry to prevent the bentonite from coming in contact with water before the flushing 
phase. A vacuum of $25 \mathrm{kPa}$ was applied to the pore space to provide support to the specimen while the cell was assembled and an equivalent cell pressure was applied. The specimen was then flushed from bottom to top, first with carbon dioxide $\left(\mathrm{CO}_{2}\right)$, and then with de-ionized, de-aired water. Flushing with water was completed over a short period of time $(<2 \mathrm{~h}$ ) with gradients adjusted (maximum hydraulic gradients of 1 and 5 for clean sand and sand-bentonite, respectively) to maintain constant water flow through the specimen. These procedures prevented caking at the base of the specimens.

Hydrometer tests conducted on soil obtained from different locations along the length of selected soil specimens showed the bentonite content to be within $\pm 0.25 \%$ (by mass of dry sand) of the target value. The void ratio distribution was estimated from the variation in water content at the top, center, and bottom of the specimen. The results showed that the values of the void ratios at the different locations were within $\pm 2.5 \%$ of the specimen average void ratio.

Following flushing, the clean sand specimens were backpressure saturated for $24 \mathrm{~h}$ with a back pressure of 200 to $400 \mathrm{kPa}$ required to achieve B-values $>0.95$ (following recommendations by Black and Lee [1973]). The sand-bentonite specimens were allowed to rest for $72 \mathrm{~h}$ to promote full hydration and swelling of the bentonite inside the specimen pore space. The duration of the rest phase was based on a study (El Mohtar 2008) of the swelling time and swelling pressure of sand-bentonite mixtures showing that a minimum time of $36 \mathrm{~h}$ is needed in order for the bentonite in the pores to hydrate and swell under atmospheric pressure. After the rest period, the sand-bentonite specimens were backpressure saturated using the same procedure as for the clean sand. Following saturation, all specimens were isotropically consolidated to the desired effective consolidation stress.

\section{Testing Procedures}

Resonant Column Tests-Resonant column tests, under both drained and undrained conditions, were performed using the Drnevich resonant column apparatus (Drnevich et al. 1978) available in the Bechtel Geotechnical Laboratory at Purdue University. The test apparatus was modified to enable top and bottom drainage, so that the specimens could be flushed first with carbon dioxide and then with water and subsequently back-pressure saturated. Resonant column tests were performed to determine the shear modulus from very small strains $\left(\sim 10^{-4} \%\right)\left(G_{\max }\right)$ up to shear strains of $10^{-2} \%$.

Additionally, the vertical alignment ball-bearing component in the Drnevich resonant column was removed to reduce friction and allow more accurate measurements at very low strains. With careful specimen preparation, the ball-bearing component was not necessary. As a result of this modification, the only physical contact between the specimen top and the loading system was through the tension spring to counteract the weight of the top platen system, a flexible accelerometer cable, and the top drainage tube.

Whereas resonant column tests are typically conducted drained and at a constant confining stress, to evaluate the non-linearity in the shear modulus with increasing shear strain, in this study both drained and undrained tests were conducted. The goal of the undrained tests was to observe the change in the linear threshold strain (the strain level at which significant shear modulus reduction begins) and the strains at which excess pore pressures were generated in the specimen. Cyclic loading (at resonance) was applied to the specimen for $15 \mathrm{~s}$ to allow us to record the measurements. During this period, about 1000 to 3000 loading cycles were applied (resonant frequencies ranged from $120 \mathrm{~Hz}$ for small strain measurements on clean sand at $193 \mathrm{kPa}$ effective stress to $61 \mathrm{~Hz}$ for large strain measurements on clean sand at $50 \mathrm{kPa}$ ). Because of the high frequencies used in resonant column tests, only the mean excess pore pressures were recorded, as it was not possible to make accurate measurements of the cyclic pore pressure with individual cycles at resonant frequencies.

Cyclic Triaxial Tests-Cyclic triaxial tests were conducted using an MTS testing system equipped with a $22 \mathrm{kN}$ hydraulic actuator. External regulators were used to control the cell and pore pressure, and an external load cell was added to measure the cyclic stresses applied. All cyclic triaxial tests were performed using a sinusoidal wave form applied at a rate of 1 cycle per second with stress reversal, starting with compression loading. The load was applied through a vertical actuator rigidly connected to the top of the specimen; the loading system allowed some lateral movement to accommodate minor misalignments. The excess pore pressure was monitored at the base of the soil specimen with loading cycles. Young's modulus can be calculated from the cyclic triaxial tests following the guidelines provided in ASTM D3999-91 and is given by Eq 3.

$$
E=\frac{L_{\mathrm{DA}}}{S_{\mathrm{DA}}} \times \frac{L_{\mathrm{s}}}{A_{\mathrm{s}}}
$$

where:

$L_{\mathrm{DA}}=$ double amplitude load (twice the deviatoric vertical stress $d \sigma_{\mathrm{v}}$ ),

$S_{\mathrm{DA}}=$ double amplitude deformation,

$L_{\mathrm{s}}=$ height of the specimen after consolidation,

$A_{\mathrm{s}}=$ area of the specimen after consolidation, and

$E=$ Young's modulus.

Because the resonant column apparatus used for testing does not allow strains in excess of $10^{-2} \%$, the cyclic data were used to derive the stiffness at higher strains.

\section{Results}

\section{Drained Resonant Column Tests}

Drained resonant column tests provided the shear modulus reduction with shear strains at a constant confining stress. Figure 1 shows the shear modulus $G$ and normalized shear modulus $G / G_{\max }$ for clean sand and sand with $3 \%$ bentonite under $100 \mathrm{kPa}$ confining stress. The solid lines in the plots represent a modified hyperbolic fit through the data points based on Eqs 4 and 5 for $G$ and $G / G_{\max }$, respectively.

$$
G=\frac{G_{\max }}{1+a\left(\gamma / \gamma_{\mathrm{r}}\right)^{b}}
$$




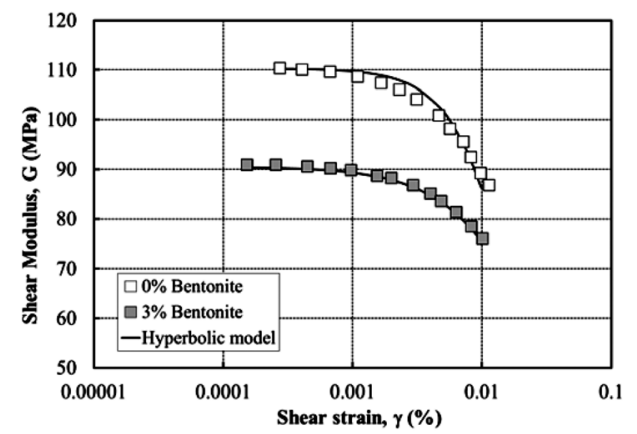

a) Measured shear modulus

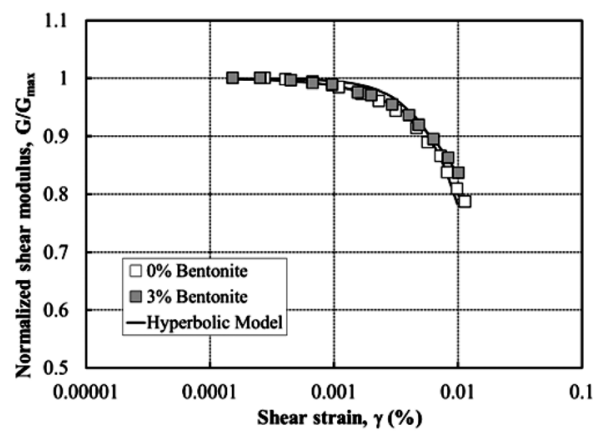

b) Normalized shear modulus

FIG. 1-Shear modulus versus shear strain for undrained conditions for $0 \%$ and $3 \%$ bentonite specimens at $100 \mathrm{kPa}$ confining pressure: (a) measured values; (b) normalized values.

$$
\frac{G}{G_{\max }}=\frac{1}{1+a\left(\gamma / \gamma_{\mathrm{r}}\right)^{b}}
$$

where:

$a$ and $b=$ fitting parameters determined using the root mean square error method,

$\gamma=$ shear strain,

$\gamma_{\mathrm{r}}=$ reference strain calculated as $\tau_{\max } / G_{\max }$, and

$\tau_{\max }=$ shear stress at failure

$\tau_{\max }$ was determined based on the shear strength envelopes reported by El Mohtar (2008) derived from consolidated undrained monotonic triaxial tests.

The shear modulus decreases with the addition of the bentonite; however, the $G / G_{\max }$ plots of both materials are similar, with the clean sand showing a marginally greater reduction in stiffness at large strains. In their study on fine soils, Vucetic and Dobry $(1988,1991)$ concluded that with increasing plasticity, the reduction curves shift to the right; that is, the soils exhibit a lower stiffness reduction rate. This shift to the right was not observed in this study, even though the added bentonite is highly plastic. However, because only small percentages of bentonite were used (less than or equal to $5 \%$ ), there was no significant effect on the PI of the mixture, and the similarity in the shapes of the reduction curves for both materials agrees with Vucetic and Dobry's findings.

The swelling pressure of sand-bentonite mixtures with such small percentages of bentonite is a few kilopascals (Komine and Ogata 2003), and therefore the bentonite swelling did not cause any volumetric changes in the sand-bentonite specimens (the confining pressure of $25 \mathrm{kPa}$ during specimen flushing and resting is much higher than the swelling pressures). As a result, as reported by El Mohtar et al. (2008a), there was no reduction in $G_{\max }$ during the resting period.

\section{Undrained Resonant Column Tests}

Figure 2 shows the shear modulus reduction curves for specimens with $0 \%, 3 \%$, and $5 \%$ bentonite, all prepared at similar skeleton void ratios and tested at $50 \mathrm{kPa}, 100 \mathrm{kPa}$, and $193 \mathrm{kPa}$. The lines in the figure are from the hyperbolic models in Eq 4. At a given shear strain, the stiffness of all specimens increased with increasing confining pressure; additionally, at any given confining stress, the maximum shear modulus $\left(G_{\max }\right)$ of the specimens containing bentonite was lower than the values for clean sand. This is similar to the $G_{\max }$ trend observed in the drained resonant column tests. El Mohtar et al. (2008a) suggested that this difference in $G_{\max }$ is due to the bentonite trapped between the sand grains because of the specimen preparation method. El Mohtar et al. (2008a) showed that this difference decreases as the confining stresses increase from $25 \mathrm{kPa}$ to $300 \mathrm{kPa}$ because of the displacement of the bentonite from the particle contacts.

Figure 3 shows the normalized shear modulus plots of the data in Fig. 2 along with the normalized excess pore pressures (excess pore pressure divided by the initial effective confining stress, $\left.\Delta u / \sigma_{\mathrm{C}}^{\prime}\right)$. Figure $3(a)$ shows the normalized shear modulus $\left(G / G_{\max }\right)$ and normalized excess pore pressures versus shear strain for the clean sand. The figure shows that with higher confining pressures, the curves shift to the right. There is a nearly identical shift in the normalized excess pore pressure curves when going from $50 \mathrm{kPa}$ to $100 \mathrm{kPa}$ to $193 \mathrm{kPa}$. At higher confining pressure, higher strains are needed to trigger pore pressure generation.

Figures $3(b)$ and 3(c) show the analogous results for specimens with $3 \%$ and $5 \%$ bentonite. The trends shown are similar to those for clean sand in that at higher confining pressure, the curves tend to shift to the right, although the shift from $100 \mathrm{kPa}$ to $193 \mathrm{kPa}$ is not as significant as that for clean sand. The strain required in order to trigger excess pore pressure generation is not as dependent on the stress level for specimens with bentonite as for the clean

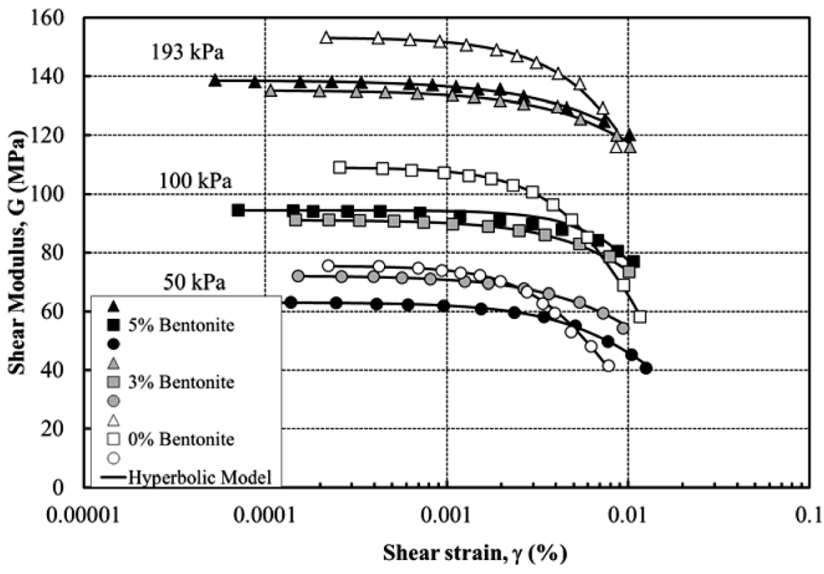

FIG. 2-Shear modulus reduction with strain from undrained tests on $0 \%$, $3 \%$, and $5 \%$ bentonite specimens at $50 \mathrm{kPa}, 100 \mathrm{kPa}$, and $193 \mathrm{kPa}$. 


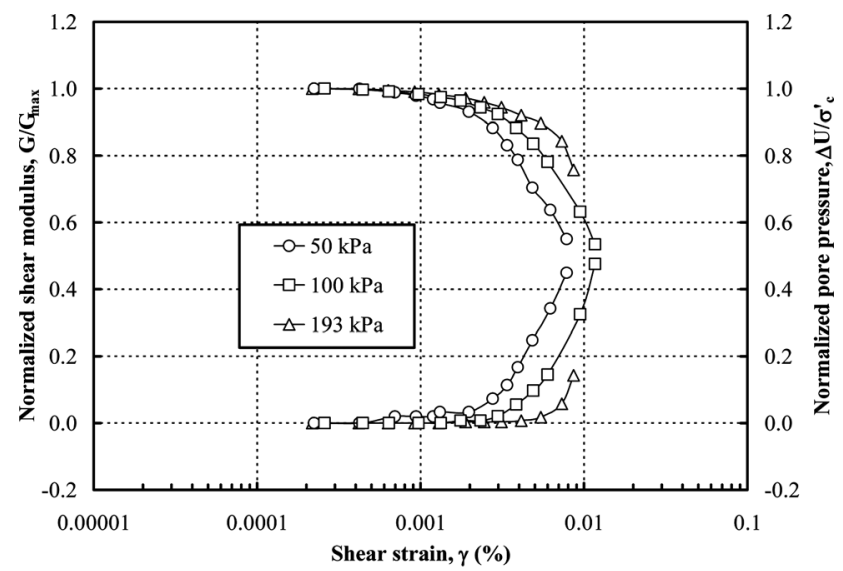

a) Clean sand

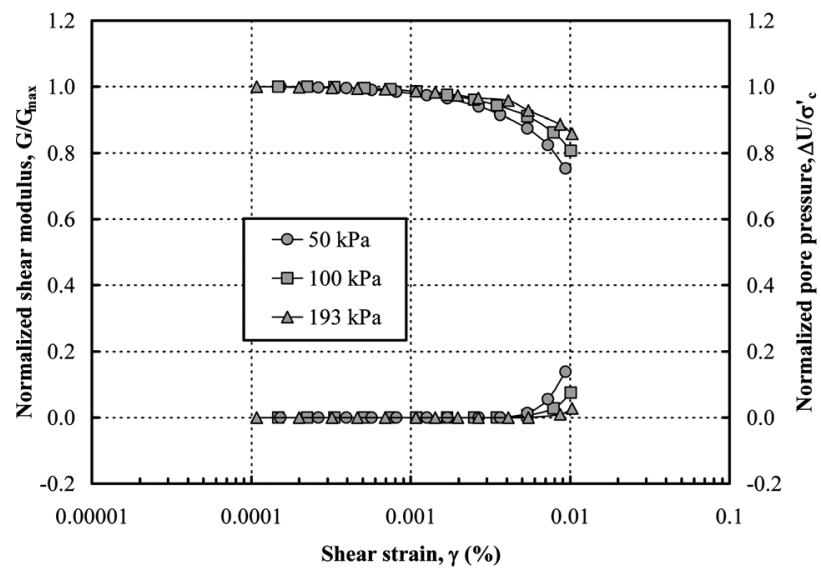

b) $3 \%$ bentonite

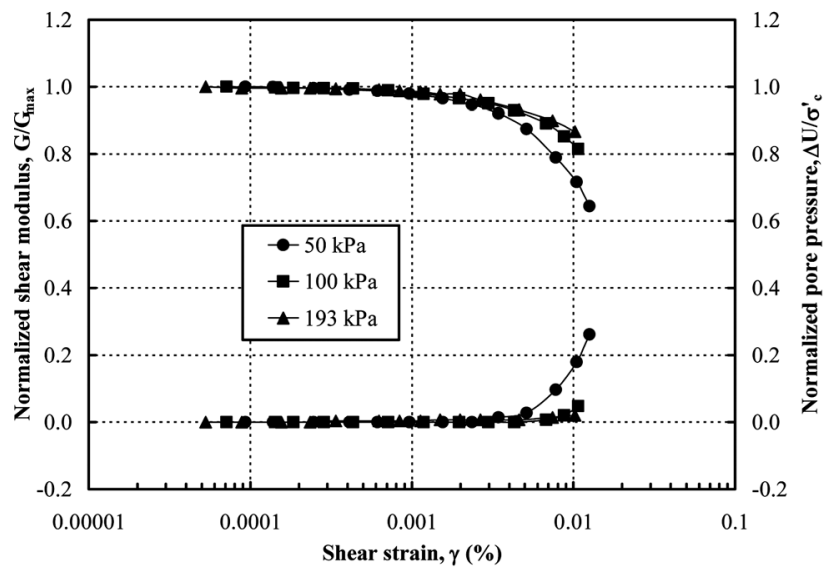

c) $5 \%$ bentonite

FIG. 3-Normalized shear modulus and pore pressure with increasing shear strain from undrained tests on (a) clean sand, (b) sand with $3 \%$ bentonite, and (c) sand with $5 \%$ bentonite at $50 \mathrm{kPa}, 100 \mathrm{kPa}$, and $193 \mathrm{kPa}$.

sand. Additionally, the normalized excess pore pressured generated in all tests with bentonite did not exceed 0.2 at a shear strain of $10^{-2} \%$ (as compared to values in excess of 0.4 for clean sand).

\section{Cyclic Triaxial Tests}

Figure 4 shows the change in stiffness with continuous cyclic loading for a clean sand specimen tested undrained at a cyclic stress

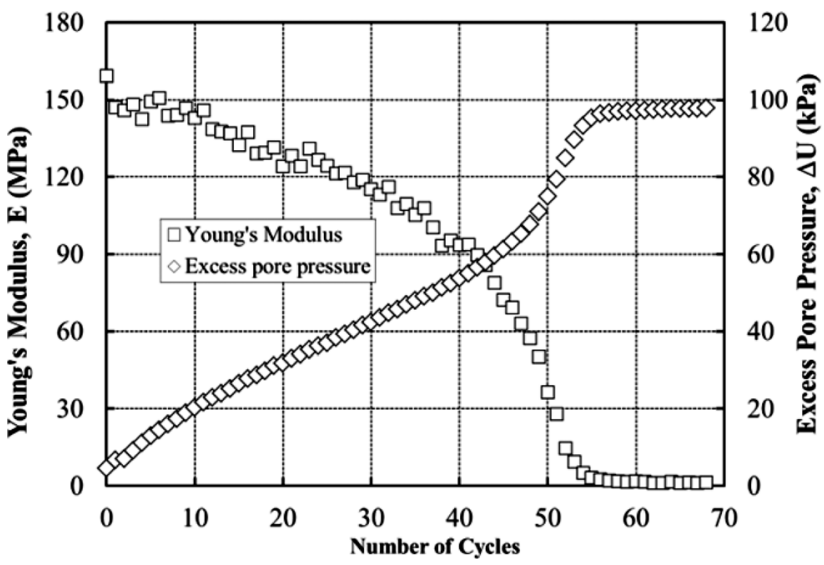

FIG. 4-Young's modulus and excess pore pressure versus number of cycles from undrained cyclic triaxial tests.

ratio of 0.11 . The stiffness decreased with continuous loading at a rate proportional to the increase in excess pore pressures; this decrease in stiffness is due to the loss of confining pressure and higher axial strains the specimen experienced as the loading cycles increased. The stiffness loss is asymptotic to a small value close to zero at large numbers of cycles. Figure 5 shows the variation of Young's modulus with cyclic axial strain (single amplitude, $\varepsilon_{\mathrm{SA}}$ ) for specimens with $0 \%, 3 \%$, and $5 \%$ bentonite. The three specimens showed similar cyclic modulus reduction with increased cyclic axial strains. At any given cyclic strain level, the stiffness of the sand specimen was lower than that of the specimens with $3 \%$ and $5 \%$ bentonite. This is a result of delayed pore pressure generation in the bentonite specimens (El Mohtar et al. 2008b).

\section{Discussion}

\section{Drained versus Undrained Stiffness Reduction for Sands}

Figure 6 shows the undrained shear modulus reduction curves from resonant column tests on clean sand at 50,100, and $193 \mathrm{kPa}$,

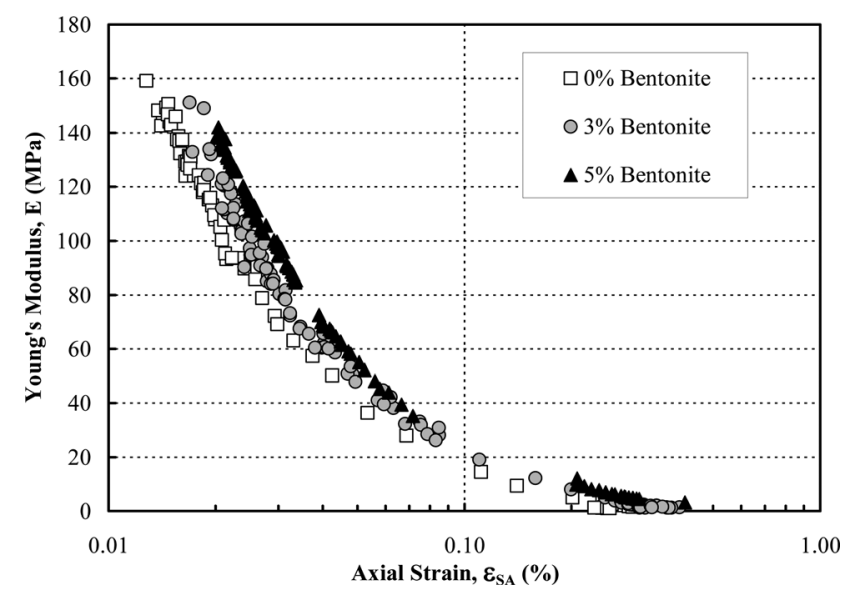

FIG. 5-Young's modulus versus axial strain for specimens with 0\%, 3\%, and $5 \%$ bentonite from undrained cyclic triaxial tests. 


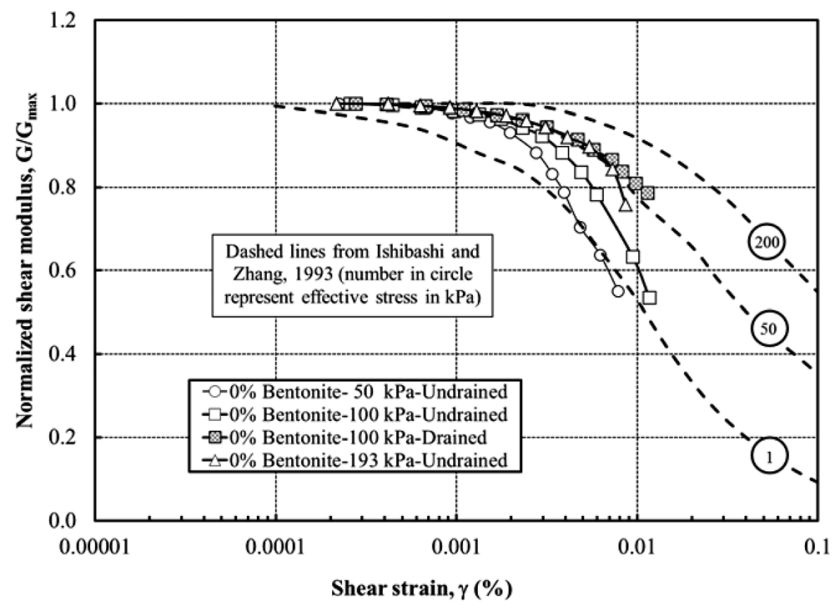

FIG. 6-Comparison of clean sand shear modulus reduction versus values from Ishibashi and Zhang (1993).

the drained shear modulus reduction curve at $100 \mathrm{kPa}$, and the results reported by Ishibashi and Zhang (1993) at 1, 50, and $200 \mathrm{kPa}$. The tests conducted by Ishibashi and Zhang were performed drained at a constant effective stress. The stiffness reduction from the drained test at $100 \mathrm{kPa}$ plots just above the $50 \mathrm{kPa}$ test by Ishibashi and Zhang. Considering the possible differences in material and void ratio, the values obtained in this study under drained conditions match the data reported by Ishibashi and Zhang well. The stiffness reduction curves for the undrained test start deviating from the drained results reported by Ishibashi and Zhang, and the rate of stiffness reduction increased significantly with increasing shear strains.

Figure 7 shows shear modulus reduction curves from drained and undrained resonant column tests for specimens with $0 \%$ and $3 \%$ bentonite at $100 \mathrm{kPa}$ confining pressure; Fig. 7(a) gives the measured values, and Fig. 7(b) gives the normalized values. For each specimen, three shear modulus reduction curves are plotted: a drained curve (Drained), an undrained curve (Undrained), and a corrected undrained curve (U-Corrected). The U-Corrected curve was obtained by correcting the undrained data for the loss of confining pressure based on Eq 6 (derived from the Hardin [1978] equation considering that the drained and undrained tests were performed on specimens with similar void ratios).

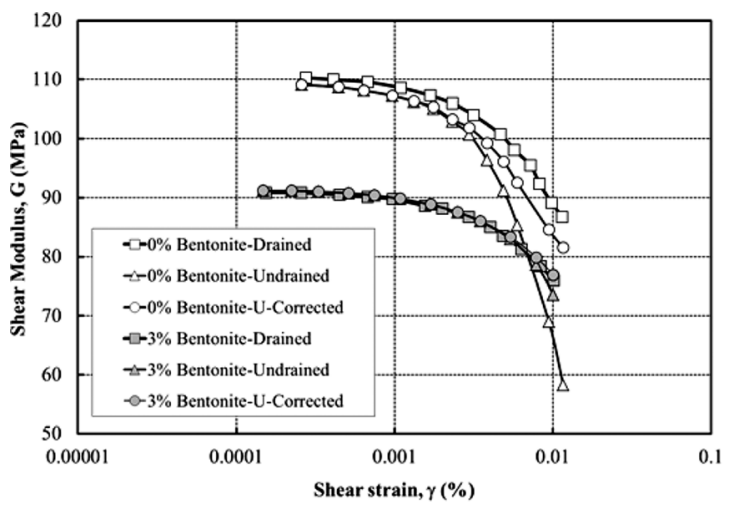

a) Measured shear modulus

$$
G_{\mathrm{U}-\text { Corrected }}=G_{u}\left(\frac{\sigma_{0}^{\prime}}{\sigma^{\prime}}\right)^{n}
$$

where:

$G_{\mathrm{U}-\text { Corrected }}=$ undrained shear modulus at a given shear strain amplitude corrected for the loss of effective stresses,

$G_{\mathrm{U}}$ and $\sigma^{\prime}=$ measured undrained shear modulus and effective stress at the same shear strain,

$\sigma_{0}^{\prime}=$ initial confining pressure $(100 \mathrm{kPa}$ in this case $)$, and

$n=$ power constant relating shear modulus to the confining pressure (obtained from El Mohtar et al. 2008a).

For the drained tests, the confining pressure remained constant throughout the test, and the corrected shear modulus values are equal to the measured ones.

At small strains below the linear elastic threshold (here defined as the strain corresponding to $G / G_{\max }=0.98$ [Ni 1987]), the shear modulus values measured from the drained and undrained (and corrected undrained) tests were similar for clean sand and for $3 \%$ bentonite specimens (strains less than $10^{-3} \%$ ). The similarity in the measured shear modulus values is expected because the undrained specimens did not generate any notable excess pore pressure, and therefore the drained and undrained specimens were tested under essentially the same effective stress.

When the normalized drained curves for $0 \%$ and $3 \%$ specimens are compared beyond the linear elastic threshold strain, which for all tests was about $10^{-3} \%$, one finds that the shear modulus reduction for clean sands occurred at lower strains than for the specimen with bentonite. The difference, though, is not as significant as that observed in the undrained case. The corrected undrained curve lies closer to the drained curve, yet not coincident with it, indicating that the effective stress loss does not completely account for the difference between the drained and undrained tests. The rate of stiffness reduction at a given strain level increased with decreasing effective stress under both drained and undrained conditions (Fig. 6). However, when excess pore pressure is generated in the specimen as the shear strain increases from $\gamma_{a}$ to $\gamma_{b}$, the specimen is at a lower effective stress, and the rate of stiffness reduction as the strain increases from $\gamma_{b}$ to $\gamma_{c}$ is greater than the stiffness reduction rate between $\gamma_{a}$ and $\gamma_{b}$. This helps to explain why the modulus reduction is greater for the corrected undrained tests than for the drained tests.

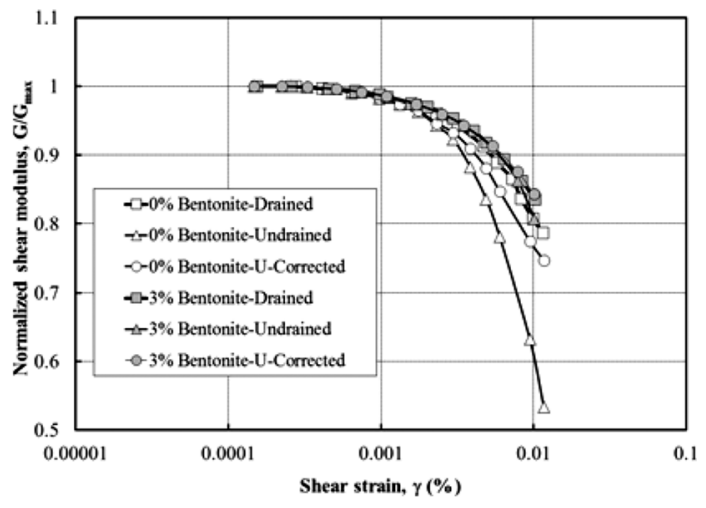

b) Normalized shear modulus

FIG. 7-Comparison of drained versus undrained normalized shear modulus reduction for specimens with $0 \%$ and $3 \%$ bentonite at $100 \mathrm{kPa}$ confining pressure. 


\section{Combined Resonant Column and Cyclic Triaxial Results}

Resonant column tests provide the means to measure the shear modulus over the $10^{-4} \%$ to $10^{-2} \%$ shear strain range, whereas cyclic and monotonic triaxial tests provide a measurement of Young's modulus at much higher (axial) strains. In order to combine the resonant column and cyclic triaxial data and obtain a more complete modulus reduction with strain curve, it is necessary to make some simplifying assumptions. Other researchers (e.g., Georgiannou et al. 1991) have shown that by assuming isotropic linear elastic behavior, it is possible to relate Young's modulus $(E)$ to the shear modulus $(G)$ using Eq 7. Similarly, the axial strain can be calculated from the shear strain using Eq 8 .

$$
\begin{aligned}
G & =\frac{E}{2(1+v)} \\
\gamma & =(1+v) \varepsilon
\end{aligned}
$$

where:

$G=$ shear modulus,

$E=$ Young's modulus,

$\nu=$ Poisson's ratio, which for the undrained condition is assumed to be equal to 0.5 ,

$\gamma=$ shear strain, and

$\varepsilon=$ axial strain

Figure 8 combines data from undrained resonant column and cyclic triaxial tests on $0 \%, 3 \%$, and $5 \%$ bentonite specimens to illustrate the reduction in shear modulus with increasing shear strains from very small $(\sim 0.0001 \%)$ to large $(\sim 1 \%)$ strains. The results from the drained resonant column tests on $0 \%$ and $3 \%$ bentonite specimens are included as well. All the data presented are from tests on specimens with an initial confining pressure of $100 \mathrm{kPa}$. Additionally, predictions based on the hyperbolic model (Eq 4) for all the resonant column tests are included and have been extrapolated to the minimum strain measured in the cyclic triaxial tests. Note that the extrapolation of the resonant column results based on the hyperbolic model, in the semi-log plot in Fig. 8, is a rough estimate of the expected values and should not be used for any quantitative analysis. For the drained tests, the extrapolated

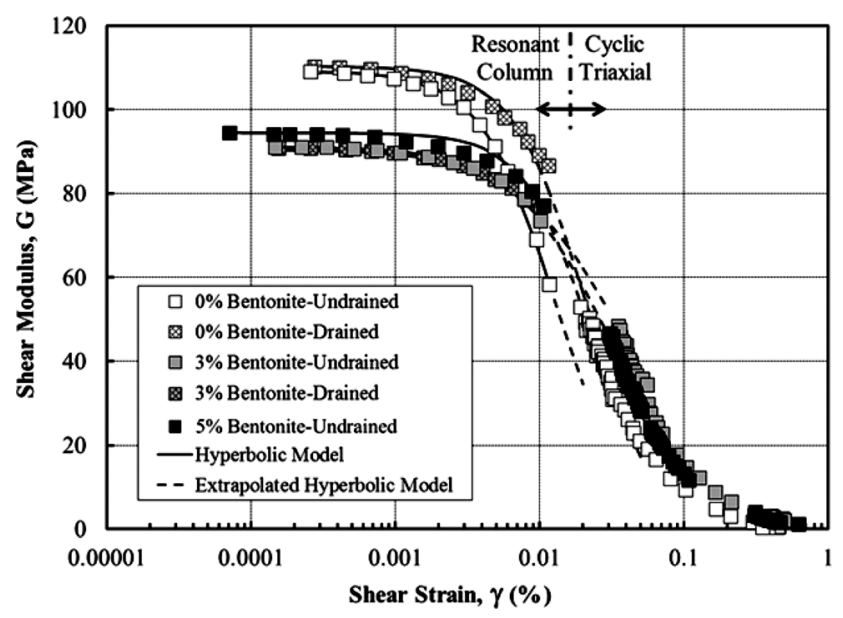

FIG. 8-Shear modulus reduction with shear strain from resonant column and cyclic triaxial tests at $100 \mathrm{kPa}$ confining pressure. resonant column data match the first cyclic triaxial measured modulus values for both $0 \%$ and $3 \%$ bentonite specimens.

For the undrained resonant column test on clean sand, the extrapolated trend line is below the data from the cyclic triaxial tests. For comparison, the first measured shear modulus from the cyclic triaxial test is $53 \mathrm{MPa}$ at $0.02 \%$ shear strain, whereas the shear modulus estimated at the same strain from the undrained resonant column extrapolated results is $34 \mathrm{MPa}$. This difference in measured shear modulus is due to pore pressure buildup in the undrained resonant column tests leading to (1) lower effective stress in the resonant column test (the effective confining stress of the specimen in the resonant column test when testing at the highest shear strain was $50 \mathrm{kPa}$, whereas the first measured shear modulus in the cyclic triaxial test was at an effective stress of $100 \mathrm{kPa}$ ) and (2) the fact that the rate of shear modulus reduction at the lower effective stress in the resonant column occurs at a higher rate than that in the cyclic triaxial test. The extrapolated undrained results are a better match with the first few cycles of the cyclic triaxial test.

In Fig. 9, the combined shear modulus data from Fig. 8 are replotted as normalized by the maximum shear modulus $\left(G_{\max }\right)$ of each test. The mean and range of expected $G / G_{\max }$ values for drained clean sand, as suggested by Seed and Idriss (1970), are included for comparison. This representation emphasizes that any given strain level, the normalized modulus of the clean sand is less than that of the bentonite specimens, indicating that the modulus reduction with the presence of bentonite is not as large as that in clean sand. The resonant column results for the drained tests and for the undrained tests for $3 \%$ and $5 \%$ bentonite specimens are consistent with the average values of $G / G_{\max }$ proposed by Seed and Idriss (1970). For the $0 \%$ bentonite specimen, the shear modulus reduction in the undrained tests accelerated after exceeding a shear strain of approximately $0.003 \%$. $G / G_{\max }$ of the clean sand approached the lower limit of the proposed range as the strains reached about $0.01 \%$. However, $G / G_{\max }$ measured using the cyclic triaxial test started at a value closer to the mean value proposed by Seed and Idriss, even though the shear strains were about $0.02 \%$. $G / G_{\max }$ from the cyclic triaxial tests for the three materials started near the mean value curve at lower strains and decreased toward the lower limit as the strains increased, implying

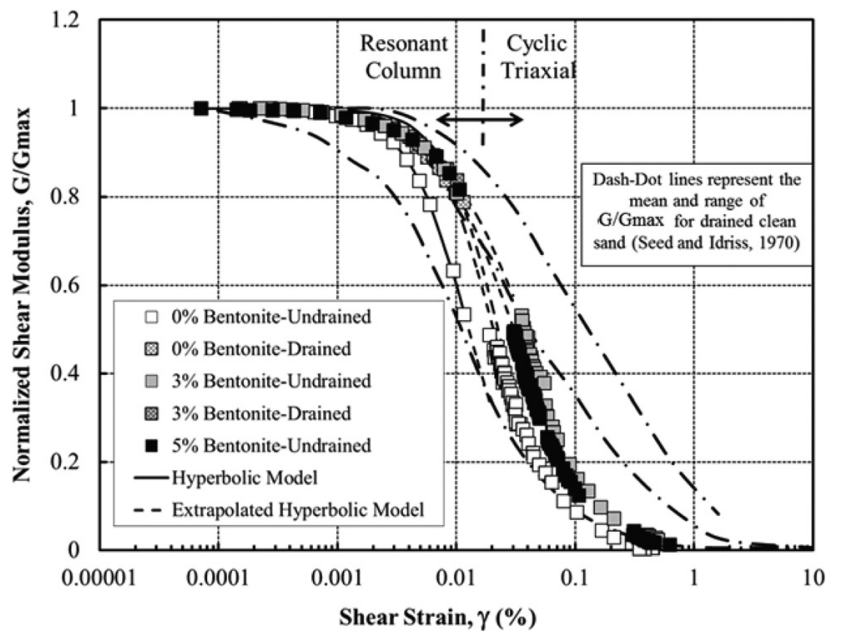

FIG. 9-Normalized shear modulus reduction with shear strain from resonant column and cyclic triaxial tests at $100 \mathrm{kPa}$ confining pressure. 
a higher rate of modulus reduction than for the drained tests proposed by Seed and Idriss.

\section{Conclusions}

This paper presents the results of drained and undrained resonant column tests and undrained cyclic triaxial tests performed on sand-bentonite specimens with $0 \%, 3 \%$, and $5 \%$ bentonite by dry mass of sand. The specimen preparation and "curing" were designed so as to allow the bentonite to freely swell within the pore space to create a bentonite suspension, rather than remain as plastic fines attached to the sand particles. The addition of bentonite resulted in a decrease in $G_{\max }$ at all confining stresses $(50,100$, and $193 \mathrm{kPa}$ ). The drained test results were consistent with the data for clean sands reported in the literature. The extrapolated hyperbolic model from the drained resonant column test matched the initial stiffness measurement from the cyclic triaxial tests, showing that the two tests can be used to obtain a stiffness reduction curve over a large range of strains. In the undrained resonant column tests, excess pore pressures were generated at much lower shear strains in clean sand specimens than in specimens with bentonite tested at the same confining stress. Although the presence of bentonite increases the strain at which the pore pressure generation is initiated, the undrained shear modulus reduction beyond that strain level is a result of three contributions:

(1) Loss of shear modulus due to the increase in the applied shear strain. Again, this behavior has been documented by many researchers (e.g., Mitchell 1960; Hardin and Drnevich 1972).

(2) Loss of shear modulus due to a decrease in effective confining stress resulting from the excess pore pressures generated under undrained conditions. The dependence of the shear modulus on the confining pressure is well documented in the literature (Hardin and Drnevich 1972) and in this study, as seen in Fig. 3.

(3) Loss of shear modulus due to an increase in the modulus reduction rate because of lower confinement. As discussed above, the shape of the modulus reduction curve is dependent on the confining stresses, and when the specimen loses confinement as a result of the generated pore pressures, the modulus reduction rate progressively increases with the additional excess pore pressure, leading to an accelerated modulus reduction that cannot be accounted for solely by compensating for the change in effective stress.

This paper explores the possibility of determining an undrained modulus reduction curve for use in predicting the appropriate shear modulus to use at cyclic strains that generate a significant amount of pore pressure. The initial results presented show that using the drained $G / G_{\max }$ to determine the shear modulus at a given strain can lead to overestimation of the value of $G$ even if a correction factor based on the reduction in effective stresses is applied.

\section{Acknowledgments}

This research was supported by the National Science Foundation, Geomechanics and Geotechnical Systems Program, under Grant No. CMS-0408739. This support is gratefully acknowledged.

\section{References}

ASTM D3999-91: Standard Test Methods for the Determination of the Modulus and Damping Properties of Soils Using Cyclic Triaxial Apparatus, Annual Book of ASTM Standards, ASTM International, West Conshohocken, PA, 2011.

ASTM D4015-07: Standard Test Methods for Modulus and Damping of Soils by Resonant-Column Method, Annual Book of ASTM Standards, ASTM International, West Conshohocken, PA, 2007.

ASTM D5311-11: Standard Test Methods for Load Controlled Cyclic Triaxial Strength of Soil, Annual Book of ASTM Standards, ASTM International, West Conshohocken, PA, 2011.

Black, D. K. and Lee, K. L., 1973, "Saturating Laboratory Samples by Back Pressure," J. Soil Mech. Found. Div., Vol. 99, pp. 75-93.

Dobry, R. and Vucetic, M., 1987, "Dynamic Properties and Seismic Response of Soft Clay Deposits," Proceedings of the International Symposium on Geotechnical Engineering of Soft Soils, Mexico City, Mexico, Aug. 13-14, International Society of Soil Mechanics and Geotechnical Engineering (ISSMGE), pp. 51-87.

Drnevich, V. P., Hardin, B. O., and Shippy, D. J., 1978, "Modulus and Damping of Soils by the Resonant Column Method," ASTM Symposium on Dynamic Geotechnical Testing, Denver, CO, June 28, 1977, ASTM International, West Conshohocken, PA, pp. 91-125.

Duncan, J. M. and Chang, C. Y., 1970, "Nonlinear Analysis of Stress-Strain in Soils," J. Soil Mech. Found. Div., Vol. 96(SM5), pp. 1629-1653.

El Mohtar, C., 2008, "Pore Fluid Engineering: An Auto-Adaptive Design for Liquefaction Mitigation," Ph.D. dissertation, Purdue University, West Lafayette, IN.

El Mohtar, C., Santagata, M., Bobet, A., Drnevich, V., and Johnston, C., 2008a, "Effect of Plastic Fines on the Small Strain Stiffness of Sand," IS-Atlanta: Fourth International Symposium, Deformation Characteristics of Geomaterials, Atlanta, GA, Sept. 22-24, International Society of Soil Mechanics and Geotechnical Engineering (ISSMGE), pp. 245-251.

El Mohtar, C., Santagata, M., Bobet, A., Drnevich, V., and Johnston, C., 2008b, "Cyclic Response of a Sand With Thixotropic Pore Fluid," ASCE Geotechnical Earthquake Engineering and Soil Dynamics Conference, Sacramento, CA, May 18-22, ASCE, Reston, VA.

Fahey, M. and Carter, J. P., 1993, "A Finite Element Study of the Pressuremeter Test in Sand Using a Nonlinear Elastic Plastic Model," Can. Geotech. J., Vol. 30, pp. 348-361.

Georgiannou, V. N., Hight, D. W., and Burland, J. B., 1991, "Behaviour of Clayey Sands under Undrained Cyclic Triaxial Loading," Geotechnique, Vol. 41, pp. 383-393.

Haldavnekar, V., Bobet, A., Santagata, M., and Drnevich, V., 2003, "Soil Treatment With a Thixotropic Fluid: An Autoadaptive Design for Liquefaction Prevention," Proceedings of the 11th International Conference on Soil Dynamics \& Earthquake Engineering and 3rd International Conference on Earthquake Geotechnical Engineering, Vol. II, Berkeley, CA, University of California, Berkeley, pp. 553-560.

Hardin, B. O., 1978, "Nature of Stress-Strain Behavior for Soils," Proceedings of the ASCE Geotechnical Engineering Division Special Conference on Earthquake Engineering and Soil Dynamics, June 19-21, 1978, pp. 3-90. 
Hardin, B. O. and Drnevich, V. P., 1972, "Shear Modulus and Damping in Soils: Measurement and Parameter Effects," $J$. Soil Mech. Found. Div., Vol. 98, pp. 603-624.

Ishibashi, I. and Zhang, X., 1993, "Unified Dynamic Shear Moduli and Damping Ratios of Sand and Clay," Soils Found., Vol. 33(1), pp. 182-191.

Ishihara, K., 1993, "Liquefaction and Flow Failure During Earthquakes," Geotechnique, Vol. 43(3), pp. 351-415.

Ishihara, K., 1996, Soil Behaviour in Earthquake Geotechnics, 1st ed., Clarendon Press, Oxford, UK.

Ishihara, K. and Koseki, J., 1989, "Discussion of Cyclic Shear Strength of Fines-containing Sands," Earthquake Geotechnical Engineering, 12th International Conference on Soil Mechanics and Foundation Engineering, Rio de Janeiro, Brazil, August 13-18, International Society of Soil Mechanics and Geotechnical Engineering (ISSMGE), pp. 101-106.

Komine, H. and Ogata, N., 2003, "New Equations for Swelling Characteristics of Bentonite-based Buffer Materials," Can. Geotech. J., Vol. 40(2), pp. 460-475.

Mitchell, J. M. 1960, "Fundamental Aspects of Thixotropy in Soils," ASCE J. Soil Mech. and Found. Div., Vol. 86, pp. 19-52.

Ni, S. H., 1987, "Dynamic Properties of Sand under True Triaxial Stress States From Resonant Column/Torsional Shear Tests," $\mathrm{Ph} . \mathrm{D}$. dissertation, Department of Civil Engineering, University of Texas at Austin, Austin, TX.

Rugg, D. A., Yoon, J., Hwang, H., and El Mohtar, C. S., 2011, "Undrained Shearing Properties of Sand Permeated With a
Bentonite Suspension for Static Liquefaction Mitigation," Geofrontiers, Dallas, TX, March 13-16, ASCE, Reston, VA.

Seed, H. B. and Idriss, I. M., 1970, "Soil Moduli and Damping Factors for Dynamic Response Analyses," Report EERC 7010, Earthquake Engineering Research Center, University of California, Berkeley, CA.

Seed, H. B., Idriss, I. M., and Arango, I., 1983, "Evaluation of Liquefaction Potential Using Field Performance Data," J. Geotech. Eng.-ASCE, Vol. 109(3), pp. 458-482.

Tokimatsu, K. and Yoshimi, Y., 1983, "Empirical Correlation of Soil Liquefaction Based on SPT N-Value and Fines Content," Soils Found., Vol. 23(4), pp. 56-74.

Vucetic, M. and Dobry, R., 1988, "Degradation of Marine Clays under Cyclic Loading," J. Geotech. Eng., Vol. 114, pp. 133-149.

Vucetic, M. and Dobry, R., 1991, "Effect of Soil Plasticity on Cyclic Response," J. Geotech. Eng., Vol. 117, pp. 89-107.

Wang, W., 1979, Some Findings in Soil Liquefaction, Water Conservancy and Hydroelectric Power Scientific Research Institute, Beijing, China.

Yasuda, S., Wakamatsu, K., and Nagase, H., 1994, "Liquefaction of Artificially Filled Silty Sands," Ground Failures Under Seismic Conditions, Geotechnical Special Publication No. 44, ASCE, Reston, VA, pp. 91-104.

Zen, K., Umehara, Y., and Hamada, K., 1978, "Laboratory Tests and In-Situ Seismic Survey on Vibratory Shear Modulus of Clayey Soils With Different Plasticities," Proceedings of the Fifth Japan Earth Quake Engineering Symposium, Tokyo, Japan, November 28-30, pp. 721-728. 